\title{
Peningkatan Hasil Belajar Melalui Penerapan Metode Pembelajaran Snowball Throwing Pada Pelajaran Pengetahuan Bahan Makanan Siswa
}

\author{
Ketut Usaningsih ${ }^{1 *}$ \\ ${ }^{1}$ SMK Negeri 2 Singaraja, Singaraja, Indonesia
}

A R T I C L E I N F O

Article history:

Received 12 February 2021

Received in revised form 30 March 2021

Accepted 05 April 2021

Available online 11 May 2021

Kata Kunci:

Hasil Belajar, Metode

Snowball Throwing.

Keywords:

Learning Outcomes,

Snowball Throwing

Method.

\begin{abstract}
A B S T R A K
Berdasarkan hasil observasi pembelajaran pengetahuan bahan makanan siswa masih cenderung pasif, sehingga dibutuhkan motode pembelajaran yang dapat membuat siswa aktif dan dapat meningkatkan hasil belajar. Penelitian ini bertujuan untuk menganalisis hasil belajar melalui penerapan metode pembelajaran Snowball Throwing pada pelajaran pengetahuan bahan makanan siswa kelas $X$. Jenis Penelitian ini adalah penelitian tindakan kelas. Subjek penelitian adalah siswa kelas $X$ Kuliner 1 SMK N 2 Singaraja berjumlah 40 siswa. Teknik pengumpulan data yang digunakan meliputi catatan lapangan, observasi, tes, dan dokumentasi. Teknik analisis data yang digunakan adalah deskriptif kuantitatif. Hasil penelitian ini menunjukkan adanya peningkatan persentase skor keaktifan belajar sebesar $14,87 \%$ dari $73,15 \%$ pada siklus I menjadi $88,02 \%$ pada siklus II, dan adanya peningkatan rata-rata dari pre test sebesar 48,71 menjadi 89,79 pada post test. Simpulan penelitian ini adalah penerapan metode pembelajaran Snowball Throwing pada pelajaran pengetahuan bahan makanan terbukti dapat
\end{abstract} meningkatkan hasil belajar siswa kelas X. Implikasi penelitian ini adalah dapat meningkatkan aktivitas siswa didalam proses pembelajaran dan dapat melatih siswa untuk berani mengemukakan pendapat, bekerja sama serta tanggung jawab.

A B S T R A K

Based on the results of observations of learning students' foodstuff knowledge, they still tend to be passive, so a learning method is needed that can make students active and can improve learning outcomes. This study aims to analyze learning outcomes through the application of the Snowball Throwing learning method in the knowledge of foodstuffs for class $X$ students. This type of research is classroom action research. The research subjects were 40 students of class $X$ Culinary 1 SMK N 2 Singaraja. Data collection techniques used include field notes, observations, tests, and documentation. The data analysis technique used is descriptive quantitative. The results of this study indicate an increase in the percentage of learning activeness score of $14.87 \%$ from $73.15 \%$ in the first cycle to $88.02 \%$ in the second cycle, and an increase in the average from the pre-test of 48.71 to 89.79 in post test. The conclusion of this study is that the application of the Snowball Throwing learning method in foodstuff knowledge lessons is proven to improve student learning outcomes in class $X$. The implication of this research is that it can increase student activity in the learning process and can train students to dare to express opinions, cooperate and be responsible.

\section{Pendahuluan}

Kemajuan suatu bangsa di masa yang akan datang tergantung dari mutu pendidikan generasi muda saat ini. Tujuan pendidikan yang harus dicapai pada hakekatnya merupakan bentuk-bentuk atau pola tingkah laku yang harus dikuasai oleh peserta didik yang meliputi pengetahuan, sikap dan keterampilan (Kurniaman \& Noviana, 2017; Kurniasari, 2017; Sutrisno, 2015). Untuk mencapai tujuan 
pendidikan tentunya harus dimulai dengan pengadaan tenaga kependidikan sampai pada usaha peningkatan mutu tenaga kependidikan atau pengajar dalam proses belajar mengajar. Tenaga kependidikan diharuskan mampu mengembangkan model pembelajaran yang tepat. Pendekatan pembelajaran yang digunakan dalam proses belajar mengajar dapat dianggap sebagai suatu jalan atau cara yang teratur untuk melakukan sesuatu.

Pendidikan dan pengajaran adalah suatu proses yang sadar tujuan. Tujuan dapat diartikan sebagai suatu usaha untuk memberikan rumusan hasil yang diharapkan siswa setelah melaksanakan pengalaman belajar. Tercapai tidaknya tujuan pembelajaran salah satunya adalah terlihat dari prestasi belajar yang diraih siswa, dengan prestasi yang tinggi para siswa mempunyai indikasi berpengetahuan yang baik (Krissandi \& Rusmawan, 2015; Kristiantari, 2015; Makaborang, 2019). Pembelajaran adalah proses, cara menjadikan orang atau makhluk hidup belajar (Putri et al., 2014; Suria et al., 2019; Yulia et al., 2019). Dalam proses pembelajaran melibatkan peran serta antara pendidik dengan peserta didik. Proses pembelajaran berlangsung di lingkungan sekolah yaitu pada ruangan kelas. Proses pembelajaran berlangsung dilengkapi dengan alat pendukung berupa fasilitas pembelajaran, materi pembelajaran, media pembelajaran, metode atau strategi pembelajaran dan lain-lainnya. Semua perlengkapan itu hanya sebagai pendukung, berlangsungnya proses pembelajaran yang terpenting adalah adanya partisipasi antara pendidik dan peserta didik.

Pendidik yang aktif akan menyampaikan materi pembelajaran dengan sebaik mungkin sehingga materi dapat diterima oleh peserta didik dengan maksimal. Pendidik juga dapat menguasai keadaan kelas sehingga peserta didik ikut terlibat aktif tidak hanya mendengarkan saja. Dalam pelaksanaan pembelajaran, pendidik juga dapat menggunakan media dan strategi pembelajaran untuk meningkatkan semangat belajar sehingga peserta didik lebih tertarik untuk memperhatikan pendidik saat menyampaikan materi pembelajaran (Inapi, 2018; Sihombing, 2018; Suparmi, 2013).

Setiap proses pembelajaran, keberhasilannya dapat diukur dari seberapa jauh hasil belajar yang dicapai peserta didik. Diukur dari segi prosesnya, artinya seberapa jauh hasil belajar dimiliki oleh peserta didik. Baik ataupun buruknya hasil belajar dapat dilihat dari hasil pengukuran yang berupa evaluasi, selain untuk mengukur hasil belajar penilaian dapat juga ditujukan kepada proses pembelajaran, yaitu untuk mengetahui sejauh mana tingkat keterlibatan peserta didik saat kegiatan pembelajaran. Semakin baik proses pembelajaran dan keaktifan peserta didik dalam mengikuti kegiatan pembelajaran maka seharusnya semakin tinggi juga hasil belajar peserta didik sesuai dengan tujuan pembelajaran yang telah dirumuskan sebelumnya (Jihad dan Haris, 2008: 20)(Masrita, 2017; Sanjaya et al., 2013; Suatri, 2015).

Menurut (Hidayat et al., 2017; Khaerunnnisa \& Pamungkas, 2018; Sukmasari \& Rosana, 2017), hasil belajar adalah pola perbuatan, nilai-nilai, pengertian-pengertian, sikap-sikap, apresiasi dan keterampilan. Hasil belajar yang menjadi objek penilaian kelas berupa kemampuan-kemampuan baru yang diperoleh siswa setelah mereka mengikuti proses belajar-mengajar tentang mata pelajaran tertentu. Dalam sistem pendidikan nasional rumusan tujuan pendidikan mengacu pada klasifikasi hasil belajar dari Bloom yang secara garis besar yaitu aspek kognitif, aspek afektif dan aspek psikomotor (Astuti, 2016; Azizah et al., 2017; Juniarta \& Winarno, 2016). Dalam proses belajar mengajar guru melakukan tugasnya tidak hanya menyampaikan materi kepada siswa, tetapi ia juga dituntut untuk membantu keberhasilan dalam menyampaikan materi pelajaran yaitu dengan cara mengevaluasi hasil belajar mengajar.

Berdasarkan hasil observasi awal yang sudah dilakukan oleh peneliti di kelas X Kuliner 1 SMK Negeri 2 Singaraja, diperoleh gambaran bahwa saat pembelajaran teori Pengetahuan Bahan Makanan peserta didik masih cenderung pasif. Dari 40 peserta didik hanya 6 peserta didik yang aktif, berani mengungkapkan pertanyaan. Pendidik juga belum menggunakan media dan strategi pembelajaran secara maksimal, sehingga saat pembelajaran sering terjadi peserta didik hanya sebagai pendengar, jarang terjadi suasana berdialog dengan pendidik. Peserta didik masih cenderung diam dan nantinya dapat mempengaruhi hasil belajar yang tidak sesuai dengan harapan. Selain itu, jika pendidik tidak meminta peserta didik untuk mencari atau membaca sumber belajar seperti buku dan hand out, peserta didik tidak memiliki inisiatif untuk membaca dan mempelajarinya. Ketika pendidik meminta peserta didik untuk mencari materi untuk pertemuan yang akan datang, masih banyak peserta didik yang tidak mencari materi dengan berbagai alasan dan pendidik harus memberi ketegasan agar peserta didik berusaha mengerjakan tugas dari pendidik.

Peserta didik diminta untuk membaca materi yang sudah disampaikan meskipun sudah diingatkan sebelumya akan dilaksanakan penilaian harian. Sebelum melaksanakan penilaian harian, pendidik harus mengulangi menyampaikan lagi atau memberi waktu kepada peserta didik untuk belajar. Walaupun sudah diulang dan diberi waktu untuk belajar, tetapi masih ada 15\% peserta didik di kelas X Kuliner 1 yang belum mencapai nilai Kriteria Ketuntasan Minimum (KKM) yang sudah ditetapkan di SMK N 2 Singaraja yaitu 80 dan harus mengikuti remidi. Keadaan seperti itu akan terus terjadi jika peserta 
didik kurang aktif dalam pembelajaran dan hal itu akan mempengaruhi pada hasil belajar siswa yang kurang maksimal.

Kenyataan tersebut menunjukkan bahwa pendidik harus menggunakan metode pembelajaran yang menekankan peran aktif peserta didik dalam kegiatan proses belajar mengajar. Pendidik harus dapat membangkitkan semangat belajar peserta didik untuk mengikuti pembelajaran sehingga peserta didik tidak hanya sebagai pendengar dan peserta didik tidak bermain sendiri tetapi akan terus konsentrasi pada pelajaran. Metode pembelajaran yang melibatkan peran aktif peserta didik diharapkan dapat meningkatkan motivasi peserta didik, keaktifan peserta didik, membangun rasa percaya diri dan rasa tanggung jawab peserta didik untuk belajar sehinggga hasil pembelajaran dapat terus meningkat (Sari, 2017; Ulya et al., 2020; Yoserizal \& Rahmi, 2019). Salah satu tipe pembelajaran kooperatif adalah dengan tipe snowball throwing.

Menurut Aka (2016); Wahyuni (2019); Yuliarni et al. (2013) pembelajaran kooperatif (cooperative learning) adalah suatu model pembelajaran dalam kelompok-kelompok kecil yang berjumlah 4-6 orang secara kolaboratif sehingga dapat merangsang siswa lebih bergairah dalam belajar. Ada berbagai macam metode pembelajaran kooperatif, salah satu metode pembelajaran kooperatif yang dimungkinkan dapat meningkatkan hasil belajar peserta didik adalah metode Snowball Throwing. Penggunaan metode pembelajaran Snowball Throwing dapat melibatkan peserta didik menjadi aktif, sehingga peserta didik tidak cenderung diam dan pembelajaran pun akan lebih menarik. Selanjutnya (Fitri et al., 2020; Qusyairi \& Sakila, 2018; Sukmady, 2017), menyatakan pembelajaran kooperatif dapat meningkatkan belajar siswa lebih baik dan meningkatkan sikap saling tolong-menolong dalam perilaku sosial. Selain itu, pembelajaran kooperatif berfokus pada penggunaan kelompok kecil siswa untuk bekerja sama dalam memaksimalkan kondisi belajar untuk mencapai tujuan belajar.

Pembelajaran kooperatif dengan tipe Snowball Throwing ini digunakan untuk mendapatkan jawaban yang dihasilkan dari diskusi siswa secara bertingkat. Dimulai dari kelompok kecil kemudian dilanjutkan dengan kelompok yang lebih besar sehingga pada akhirnya akan memunculkan dua atau tiga jawaban yang telah disepakati oleh siswa secara berkolompok. Strategi ini akan berjalan dengan baik jika materi yang dipelajari menuntut siswa yang berpikir analisis bahkan mungkin sintetis(Darmawan, 2014; Ramadhani, 2017; Said et al., 2019).

Melalui penerapan metode pembelajaran Snowball Throwing diharapkan dapat membantu pendidik dalam mengatasi masalah pembelajaran seperti meningkatkan hasil belajar peserta didik. Kelebihan penerapan metode pembelajaran Snowball Throwing ini yaitu akan melibatkan peran aktif peserta didik dan melalui penerapan metode pembelajaran Snowball Throwing, dapat melatih peserta didik untuk berani mengemukakan pendapat, bekerja sama dan tanggung jawab. (Lestari et al., 2017; Suria et al., 2019; Yoserizal \& Rahmi, 2019).

Penelitian tindakan kelas tentang metode pembelajaran Snowball Throwing ini didukung dengan hasil penelitian-penelitian sebelumnya seperti: (1) penelitian yang dilakukan oleh (Yoserizal \& Rahmi, 2019), yang mendapatkan hasil yaitu adanya peningkatan aktivitas belajar siswa antara model cooperative learning tipe Snowball Throwing dengan tipe think pair share; (2) penelitian yang dilakukan oleh (Lestari et al., 2017), yang mendapatkan hasil yaitu model pembelajaran Snowball Throwing berbasis lagu-lagu anak terbukti berpengaruh terhadap kompetensi pengetahuan PKN; (3) penelitian yang dilakukan oleh (Suria et al., 2019), yang mendapatkan hasil yaitu penerapan model pembelajaran Snowball Throwing berbantuan media audiovisual terdapat pengaruh yang signifikan terhadap hasil belajar Bahasa Indonesia siswa.

Penelitian ini bertujuan untuk menganalisis hasil belajar melalui penerapan metode pembelajaran Snowball Throwing pada pelajaran pengetahuan bahan makanan siswa kelas X Kuliner 1 SMK Negeri 2 singaraja semester genap tahun pelajaran 2019/2020.

\section{Metode}

Penelitian ini merupakan jenis Penelitian Tindakan Kelas (Classroom Action Research) dan termasuk dalam ruang lingkup penelitian terapan (Applied Research) yang menggabungkan antara pengetahuan, penelitian dan tindakan. Desain dalam penelitian ini menggunakan model yang diciptakan oleh Kemmis dan Taggart (Sudirman, 2016; Tembang et al., 2019; Yuliarni et al., 2013). Prosedur penelitian tindakan dapat di bagi menjadi empat tahap kegiatan pada satu putaran (siklus) yaitu, perencanaan, tindakan, observasi, dan refleksi. Kegiatan dan observasi digabung dalam satu waktu, yaitu pada saat dilaksanakan tindakan sekaligus dilaksanakan observasi. Hasil observasi kemudian direfleksikan untuk merencanakan tindakan tahap selanjutnya. Siklus tersebut dilakukan secara terusmenerus sampai peneliti merasakan puas terhadap hasil tindakan tersebut dan masalah dapat terselesaikan serta peningkatan hasil belajar sudah maksimal atau tidak perlu ditingkatkan kembali. 
Penelitian ini dilaksanakan di kelas X Kuliner 1 SMK Negeri 2 Singaraja, yang beralamat di Jalan Srikandi no. 9 Singaraja. Penelitian ini dilaksanakan pada bulan Januari 2020 sampai dengan Maret 2020. Adapun tahapan yang dilakukan adalah tahap persiapan, tahap pelaksanaan dan tahap pelaporan. Subjek dalam penelitian ini adalah siswa kelas X Kuliner 1 SMK Negeri 2 Singaraja dan objek penelitian yaitu keaktifan dan hasil belajar pengetahuan bahan makanan siswa kelas X Kuliner 1 melalui penerapan metode pembelajaran Snowball Throwing. Metode pengumpulan data yang digunakan pada penelitian ini adalah metode observasi dan tes. Metode observasi digunakan untuk mengumpulkan data keaktifan belajar siswa, sedangkan metode tes digunakan untuk mengumpulkan data hasil belajar siswa. Selanjutnya untuk kegiatan analisis data, metode analisis data yang digunakan pada penelitian ini adalah metode analisis data deskriptif kuantitatif. Adapun kriteria keberhasilan tindakan adalah apabila setelah penggunaan metode Snowball Throwing terjadi peningkatan keaktifan belajar dan hasil belajar siswa.

\section{Hasil dan Pembahasan}

Metode pembelajaran Snowball Throwing adalah salah satu model pembelajaran kooperatif. Pelaksanaan Pembelajaran Pengetahuan Bahan Makanan dengan metode Snowball Throwing meliputi: (1) siswa dikomunikasikan tentang kompetensi dan tujuan yang akan dicapai. Hal ini dilakukan agar siswa tahu apa yang akan mereka capai dalam setiap pembelajaran; (2) siswa diberi pemahaman mengenai metode pembelajaran Snowball Throwing sehingga siswa lebih paham saat pelaksaan pembelajaran dengan metode tersebut; (3) siswa diarahkan untuk membentuk kelompok menjadi 5 kelompok, masingmasing kelompok beranggotakan 4-5 siswa, salah satu siswa perwakilan dari setiap kelompok diberi tugas untuk menjelaskan materi kepada teman kelompoknya; (4) setiap siswa dari tiap-tiap kelompok diminta untuk membuat satu pertanyaan, kemudian disatukan dan dimasukkan dalam balon. Selanjutnya balon akan di lempar kepada kelompok lain, dan setiap siswa akan menjawab pertanyaan yang sudah didapat dari balon kelompok lain; (5) siswa bersama dengan peneliti mengecek jawaban dan pertanyaan dari masing-masing siswa apakah sudah sesuai atau belum. Berdasarkan pengamatan peneliti, siswa lebih antusias selama mengikuti pembelajaran menggunakan metode Snowball Throwing. Hal ini ditunjukkan saat pembelajaran siswa lebih banyak aktif. Siswa berani mengajukan pertanyaan apabila ada yang belum dipahami. Siswa percaya diri membuat pertanyaan, menjawab pertanyaan. Siswa mengikuti permainan melempar bola dengan semangat.

Berdasarkan uraian sebelumnya, dapat diketahui bahwa pembelajaran menggunakan metode Snowball Throwing dapat meningkatkan keaktifan belajar siswa. Hal ini dibuktikan dengan data yang diperoleh dari observasi pada saat pelaksanaan pembelajaran. Peningkatan persentase skor keaktifan belajar yaitu sebesar $14,87 \%$ dari $73,15 \%$ pada siklus I menjadi $88,02 \%$ pada siklus II. Hasil ini sejalan dengan hasil penelitian yang dilakukan oleh Hardini dan Arlita (2017) dengan judul Penerapan Metode Snowball Throwing Berbantuan Media Konkret Untuk Meningkatkan Keaktifan dan Hasil Belajar IPA Siswa Kelas IV Sekolah Dasar. Hasil penelitian menunjukkan melalui metode Snowball Throwing berbantuan media konkret dapat meningkatkan keaktifan dan hasil belajar IPA siswa Sekolah Dasar. Hal ini dapat dilihat dari skor awal keaktifan belajar pada siklus I sebesar 3,625 (90,62\%) meningkat di siklus II menjadi 3,81 (95,25\%). Hasil belajar siswa secara kognitif meningkat dari siklus I pencapaian ketuntasan secara klasikal rata-rata kelas mencapai $65,22 \%$ dengan rata-rata kelas 70,86 meningkat di siklus II menjadi 91,30\% dengan rata-rata kelas sebesar 79,33.

Berdasarkan hasil observasi disimpulkan bahwa metode pembelajaran Snowball Throwing dapat menempatkan siswa menjadi lebih aktif. Siswa lebih percaya diri untuk berani mengemukakan pendapat, membuat pertanyaan dan menjawab pertanyaan. Selain itu, siswa juga lebih disiplin dan bertanggung jawab dalam mengikuti pembelajaran.

Selain metode Snowball Throwing dapat meningkatkan keaktifan siswa dalam belajar, metode Snowball Throwing juga dapat meningkatkan hasil belajar siswa. Hal tersebut dibuktikan dengan data hasil penelitian yang menunjukkan peningkatan rata-rata perolehan nilai pre test dan post test. Pre test dilakuakan sebelum pelaksanaan siklus I dan siklus II, sedangkan post test dilakukan setelah siklus I dan siklus II. Rata-rata yang diperoleh saat pre test sebesar 49,17 meningkat pada post test yaitu sebesar 89,79. Pada saat pre test hanya 2 siswa yang sudah mencapai KKM (Kriteria Ketuntasan Minimum), sedangkan saat post test semua siswa sudah mencapai KKM.

Pembelajaran kooperatif dengan tipe Snowball Throwing ini digunakan untuk mendapatkan jawaban yang dihasilkan dari diskusi siswa secara bertingkat. Dimulai dari kelompok kecil kemudian dilanjutkan dengan kelompok yang lebih besar sehingga pada akhirnya akan memunculkan dua atau tiga jawaban yang telah disepakati oleh siswa secara berkolompok. Strategi ini akan berjalan dengan baik jika materi yang dipelajari menuntut siswa yang berpikir analisis bahkan mungkin sintetis (Darmawan, 2014; Ramadhani, 2017; Said et al., 2019). 
Melalui penerapan metode pembelajaran Snowball Throwing diharapkan dapat membantu pendidik dalam mengatasi masalah pembelajaran seperti meningkatkan hasil belajar peserta didik. Kelebihan penerapan metode pembelajaran Snowball Throwing ini yaitu akan melibatkan peran aktif peserta didik dan melalui penerapan metode pembelajaran Snowball Throwing, dapat melatih peserta didik untuk berani mengemukakan pendapat, bekerja sama dan tanggung jawab. (Lestari et al., 2017; Suria et al., 2019; Yoserizal \& Rahmi, 2019).

Penelitian tindakan kelas tentang metode pembelajaran Snowball Throwing ini didukung dengan hasil penelitian-penelitian sebelumnya seperti: (1) penelitian yang dilakukan oleh (Yoserizal \& Rahmi, 2019), yang mendapatkan hasil yaitu adanya peningkatan aktivitas belajar siswa antara model cooperative learning tipe Snowball Throwing dengan tipe think pair share; (2) penelitian yang dilakukan oleh (Lestari et al., 2017), yang mendapatkan hasil yaitu model pembelajaran Snowball Throwing berbasis lagu-lagu anak terbukti berpengaruh terhadap kompetensi pengetahuan PKN; (3) penelitian yang dilakukan oleh (Suria et al., 2019), yang mendapatkan hasil yaitu penerapan model pembelajaran Snowball Throwing berbantuan media audiovisual terdapat pengaruh yang signifikan terhadap hasil belajar Bahasa Indonesia siswa.

Penelitian ini memiliki implikasi penelitian yaitu penerapan metode pembelajaran Snowball Throwing dapat meningkatkan aktivitas siswa didalam proses pembelajaran dan dapat melatih siswa untuk berani mengemukakan pendapat, bekerja sama serta tanggung jawab.

\section{Simpulan}

Berdasarkan hasil penelitian dan pembahasan dapat disimpulkan bahwa penerapan metode pembelajaran Snowball Throwing pada pelajaran pengetahuan bahan makanan terbukti dapat meningkatkan hasil belajar siswa kelas X kelas X Kuliner 1 SMK Negeri 2 singaraja semester genap tahun pelajaran 2019/2020. Implikasi penelitian ini adalah dapat meningkatkan aktivitas siswa didalam proses pembelajaran dan dapat melatih siswa untuk berani mengemukakan pendapat, bekerja sama serta tanggung jawab.

\section{Daftar Rujukan}

Aka, K. A. (2016). Model Quantum Teaching Dengan Pendekatan Cooperative Learning Untuk Meningkatkan Kualitas Pembelajaran PKn. Jurnal Pedagogia, 5(1), 35-46. https://doi.org/10.21070/pedagogia.v5i1.87

Astuti, A. P. (2016). Pengembangan Instrumen Penilaian Kompetensi Membaca Pada Mata Pelajaran Bahasa Indonesia Kelas VII BERBASIS QUIPPER SCHOOL. Jinop (Jurnal Inovasi Pembelajaran), 2(2), 334-350. https://doi.org/10.22219/jinop.v2i2.3635

Azizah, N., Wati, M., Salam, A., \& Mahtari, S. (2017). Pengembangan Instrumen Kognitif Keterampilan Proses Sains Siswa SMP pada Materi Pesawat Sederhana. Berkala Ilmiah Pendidikan Fisika, 5(3), 340-350. https://doi.org/10.20527/bipf.v5i3.3933

Darmawan, H. (2014). Peningkatan Kreatifitas Mahasiswa Dalam Merancang Media Pembelajaran Multimedia IPA Berbasis Animasi Melalui Model Cooperative Learning. Jurnal Edukasi, 12(2), 193-204. https://doi.org/10.31571/edukasi.v12i2.155

Fitri, R., Neviyarni, N., \& Zikri, A. (2020). Pembelajaran PKn Dengan Model Cooperative Learning Tipe Talking Stick Di Sekolah Dasar. Jurnal Basicedu, 4(1), 183-193. https://doi.org/10.31004/basicedu.v4i1.322

Hidayat, S. R., Setyadin, A. H., Hermawan, H., Kaniawati, I., Suhendi, E., Siahaan, P., \& Samsudin, A. (2017). Pengembangan Instrumen Tes Keterampilan Pemecahan Masalah pada Materi Getaran, Gelombang, dan Bunyi. Jurnal Penelitian \& Pengembangan Pendidikan Fisika, 3(2), 157-166. https://doi.org/10.21009/1.03206

Inapi, M. L. (2018). Pengaruh Model Pembelajaran Kooperatif Terhadap Motivasi Dan Hasil Belajar Siswa Pada Materi Sistem Koloid. PEMBELAJAR: Jurnal Ilmu Pendidikan, Keguruan, Dan Pembelajaran, 2(1), 12. https://doi.org/10.26858/pembelajar.v2i1.4135

Juniarta, A. T., \& Winarno, M. E. (2016). Pengembangan Instrumen Penilaian Pengetahuan Mata Pelajaran Pendidikan Jasmani Olahraga Dan Kesehatan (PJOK) Kelas XI Semester Gasal. Jurnal Pendidikan: Teori, Penelitian, Dan Pengembangan, 1(8). https://doi.org/https://doi.org/10.17977/jp.v1i8.6704 
Khaerunnnisa, E., \& Pamungkas, A. S. (2018). Pengembangan Instrumen Kecakapan Matematis Dalam Konteks Kearifan Lokal Budaya Banten Pada Materi Bangun Ruang Sisi Datar. Kreano: Jurnal Matematika Kreatif-Inovatif, 9(1). https://doi.org/10.15294/kreano.v9i1.11210

Krissandi, A. D. S., \& Rusmawan, R. (2015). Kendala Guru Sekolah Dasar Dalam Implementasi Kurikulum 2013. Jurnal Cakrawala Pendidikan, 3(3), 457-467. https://doi.org/10.21831/cp.v3i3.7409

Kristiantari, R. (2015). Analisis Kesiapan Guru Sekolah Dasar dalam Mengimplementasikan Pembelajaran Tematik Integratif Menyongsong Kurikulum 2013. JPI (Jurnal Pendidikan Indonesia), 3(2), 460470. https://doi.org/10.23887/jpi-undiksha.v3i2.4462

Kurniaman, O., \& Noviana, E. (2017). Penerapan Kurikulum 2013 Dalam Meningkatkan Keterampilan, Sikap, Dan Pengetahuan. Primary: Jurnal Pendidikan Guru Sekolah Dasar, 6(2). https://doi.org/10.33578/jpfkip.v6i2.4520

Kurniasari, F. (2017). Implementasi Pendekatan Saintifik Pada Penugasan Aktivitas Di Buku Teks Bahasa Indonesia Kelas VII SMP Berdasarkan Kurikulum 2013. Jurnal Pendidikan Edutama, 4(1), 9-26. https://doi.org/10.30734/jpe.v4i1.44

Lestari, N. M., Suniasih, N. W., \& Darsana, I. W. (2017). Pengaruh Model Pembelajaran Snowball Throwing Berbasis Lagu - Lagu Anak Terhadap Kompetensi Pengetahuan PKN. Journal of Education Technology, 1(3), 163-168. https://doi.org/10.23887/jet.v1i3.12500

Makaborang, Y. (2019). Evaluasi Implementasi Kurikulum 2013 Mata Pelajaran Biologi Di SMA Negeri. Kelola: Jurnal Manajemen Pendidikan, 6(2), 130-145. https://doi.org/10.24246/j.jk.2019.v6.i2.p130-145

Masrita, M. (2017). Meningkatkan Hasil Belajar PKn Siswa Kelas IV Melalui Pembelajaran Kooperatif Model Make A Match di SDN 15 Batipuh, Kabupaten Tanah Datar, Sumatera BaratMeningkatkan Hasil Belajar PKn Siswa Kelas IV Melalui Pembelajaran Kooperatif Make A Match di SDN 15 B. Al Ibtida: Jurnal Pendidikan Guru MI, 4(2), 179. https://doi.org/10.24235/al.ibtida.snj.v4i2.1526

Putri, I. G. A. C. A., Putra, D. K. N. S., \& Zulaikha, S. (2014). Pengaruh Metode Pembelajaran SQ3R Terhadap Hasil Belajar Bahasa Indonesia Kelas V SD. Mimbar PGSD Undiksha, 2(1). https://doi.org/10.23887/jjpgsd.v2i1.2471

Qusyairi, L. A. H., \& Sakila, J. (2018). Pengaruh Model Cooperative Learning Tipe Inside-Outside Circle (IOC) terhadap Prestasi Belajar dengan Memperhatikan Minat Belajar Matematika. Palapa: Jurnal Studi Keislaman Dan Ilmu Pendidikan, 6(1), 34-49. https://doi.org/10.36088/palapa.v6i1.57

Ramadhani, S. P. (2017). Pengaruh Pendekatan Cooperative Learning Tipe (TPS) Think, Pair, and Share Terhadap Hasil Belajar PKn di Sekolah Dasar. Premiere Educandum : Jurnal Pendidikan Dasar Dan Pembelajaran, 7(2), 124-134. https://doi.org/10.25273/pe.v7i2.1653

Said, I. M., Sutadji, E., \& Sugandi, M. (2019). Pengembangan Bahan Ajar Berbasis Cooperative Learning Dengan Pendekatan Saintifik Untuk Siswa Smk Se-Kota Malang Program Keahlian Teknik Ototronik. Jurnal Pendidikan: Teori, Penelitian Dan Pengembangan, 1(2), 265-270. https://doi.org/10.17977/jp.v1i2.6131

Sanjaya, B., Wati, M., \& An'nur, S. (2013). Meningkatkan Hasil Belajar Siswa Melalui Penerapan Pembelajaran Kooperatif Tipe Think Pair-Share(TPS). Berkala Ilmiah Pendidikan Fisika, 1(3), 278289. https://doi.org/10.20527/bipf.v1i3.887

Sari, D. M. (2017). Analysis of Students' Mathematical Communication Ability By Using Cooperative Learning Talking Stick Type. Infinity Journal, 6(2), 183-194. https: //doi.org/10.22460/infinity.v6i2.p183-194

Sihombing, L. (2018). Upaya Meningkatkan Motivasi Belajar PKN Siswa Kelas VII.4 Melalui Penerapan Model Pembelajaran Kooperatif Dengan Teknik Keliling Kelas Di SMP Negeri 21 Pekanbaru. Dinamisia-Jurnal Pengabdian Kepada Masyarakat, 2(1), 84-90. https://doi.org/10.31849/dinamisia.v2i1.1095

Suatri, S. (2015). Pemahaman Konsep Perubahan dan Kegunaan Benda dengan Metode Smart Game \& Pembelajaran Kooperatif Tipe Make A Match dalam Mata Pelajaran IPA di SDN 12 Nan Sabaris. Jurnal Konseling Dan Pendidikan, 3(3), 56-61. https://doi.org/10.29210/13300

Sudirman, S. (2016). Penerapan Model Pembelajaran Think Pair Share Untuk Meningkatkan Hasil Belajar 
IPA Siswa. Jurnal Pendidikan Fisika, 4(1), 59-67. https://doi.org/10.24127/jpf.v4i1.394

Sukmady, F. W. (2017). Meningkatkan Kemampuan Berempati Anak Usia 5-6 Tahun Melalui Cooperative Learning. Jurnal Penelitian Dan Pengembangan Pendidikan Anak Usia Dini, 4(2). https://doi.org/10.30870/jpppaud.v4i2.4650

Sukmasari, V. P., \& Rosana, D. (2017). Pengembangan penilaian proyek pembelajaran IPA berbasis discovery learning untuk mengukur keterampilan pemecahan masalah. Jurnal Inovasi Pendidikan IPA, 3(1), 101-110. https://doi.org/10.21831/jipi.v3i1.10468

Suparmi, S. (2013). Pembelajaran Kooperatif dalam Pendidikan Multikultural. Jurnal Pembangunan Pendidikan: Fondasi Dan Aplikasi, 1(1), 108-118. https://doi.org/10.21831/jppfa.v1i1.1055

Suria, M. D. O., Suwatra, I. W., \& Murda, N. (2019). Pengaruh Model Pembelajaran Snowball Throwing Berbantuan Media Audiovisual terhadap Hasil Belajar Bahasa Indonesia. Jurnal Ilmiah Sekolah Dasar, 3(1), 89. https://doi.org/10.23887/jisd.v3i1.17662

Sutrisno. (2015). Penilaian pembelajaran tematik pada kurikulum 2013 di sekolah dasar. Jurnal Sekolah Dasar, 1(1), 12-17. http://journal2.um.ac.id/index.php/sd/article/view/1356

Tembang, Y., Harmawati, D., \& Rahajaan, J. P. (2019). Peningkatan Hasil Belajar IPA Siswa Melalui Penerapan Model Pembelajaran Kooperatif Tipe Group Investigation di Sekolah Dasar. Jurnal Ilmiah Sekolah Dasar, 3(2), 230-237.

Ulya, F., Rc, A. R., \& Sulistyorini, S. (2020). The Effectiveness of Project-Based Learning Model and Talking stickType of Cooperative Learning Model on the Quran-Hadith Subject Learning Outcomes. Innovative Journal of Curriculum and Educational Technology, 9(2), 87-93. https://doi.org/https://doi.org/10.15294/ijcet.v9i2.40173

Wahyuni, P. (2019). The Effect of Cooperative Learning Type Student Teams Achievement Division (STAD) on Understanding Mathematical Concepts in Class VIII Students of MTs N Pekanbaru. International Journal of Trends in Mathematics Education Research, 2(4), 168-172. https://doi.org/10.33122/ijtmer.v2i4.72

Yoserizal, \& Rahmi, U. (2019). Perbedaan Aktivitas Belajar Siswa Antara Model Cooperative Learning Tipe Snowball Throwing Dengan Tipe Think Pair Share. Jurnal Basicedu, 3(2), 1055-1064. https://doi.org/10.31004/basicedu.v3i4.247

Yulia, D. S. F., Wahjoedi, W., \& Sapto, A. (2019). Pengaruh Metode Pembelajaran SQ3R Terhadap Hasil Belajar Bahasa Indonesia. Jurnal Pendidikan, 4(6). https://doi.org/10.17977/jptpp.v4i6.12537

Yuliarni, E., Luawo, M. I. R., \& Karsih, K. (2013). Pengaruh Penerapan Model Cooperative Learning Tipe STAD (Student Teams Achievement Division) Dalam Layanan Bimbingan Klasikal Terhadap Keterampilan Belajar Siswa Dalam Membaca Dengan Teknik SQ3R (Studi Pre-Eksperimen Pada Siswa Kelas X-F Di SMAN 8 Bogor). Insight: Jurnal Bimbingan Konseling, 2(1), 25-31. https://doi.org/10.21009/INSIGHT.021.05 